\title{
Ventricular Non-Compaction: About the First Cases Reported in Lomé (Togo)
}

\author{
Soodougoua Baragou ${ }^{1}$, Soulemane Pessinaba ${ }^{2 *}$, Tchalla Abéna ${ }^{3}$, Ekpé Togbossi², \\ Wiyaou Kaziga ${ }^{2}$, Komlavi Yayehd ${ }^{2}$, Mohamed Kpélafia ${ }^{2}$, Nkenon Watani N'Da ${ }^{2}$, \\ El Nassirine Oloudé1, Machihude Pio ${ }^{4}$, Findibe Damorou ${ }^{1}$ \\ ${ }^{1}$ Cardiology Department, Sylvanus Olympio Teaching Hospital, Lomé, Togo \\ ${ }^{2}$ Cardiology Department, Campus Teaching Hospital, Lomé, Togo \\ ${ }^{3}$ Cardiology Department, Tomde Hospital, Kara, Togo \\ ${ }^{4}$ Cardiology Department, Kara Teaching Hospital, Kara, Togo \\ Email: *spessinaba@yahoo.fr
}

How to cite this paper: Baragou, S., Pessinaba, S., Abéna, T., Togbossi, E., Kaziga, W., Yayehd, K., Kpélafia, M., N’Da, N.W., Oloudé, E.N., Pio, M. and Damorou, F. (2020) Ventricular Non-Compaction: About the First Cases Reported in Lomé (Togo). World Journal of Cardiovascular Diseases, 10, 775-783.

https://doi.org/10.4236/wjcd.2020.1012074

Received: November 23, 2020

Accepted: December 7, 2020

Published: December 10, 2020

Copyright $\odot 2020$ by author(s) and Scientific Research Publishing Inc. This work is licensed under the Creative Commons Attribution International License (CC BY 4.0).

http://creativecommons.org/licenses/by/4.0/

\begin{abstract}
Introduction: Ventricular non-compaction, a cardiomyopathy recently described as likely to be rare, belongs to the group of unclassified cardiomyopathy according to European Society of Cardiology. Few studies have been published on the ventricular non-compaction in sub-Saharan Africa. We aim to find out the various aspects, being diagnosis, therapeutic, in Togolese patients carrying the ventricular non-compaction. Methodology: This is a three-year prospective and descriptive study conducted from January 2017 to December 2019 in the two University Hospital of Lomé. Patients having echocardiographic criteria of ventricular non-compaction were included in our study. Results: 10 patients (6 men and 4 women) were diagnosed for ventricular non-compaction during the study period. The mean age of patients was 32.3 years. The most frequent clinical manifestation was heart failure (7 patients). The main electrocardiogram anomaly was left ventricle hypertrophy ( 9 patients). The preferential segments were: apical ( 9 cases), apicolateral ( 8 cases), and septoapical (7 cases). The average ratio of non-compaction/compaction was 3.31. The main complication was thromboembolic event (4 patients). Angiotensin converting enzyme inhibitors and beta-blockers were essentially the medicines used. After a three (3) year follow-up, two (2) of the patients died. Conclusion: Tough ventricular non-compaction has been recently described. It is present in Togo. It displays many clinical manifestations and the prognosis is often guarded.
\end{abstract}

\section{Keywords}

Ventricular Non-Compaction, Hypertrophy, Sub-Saharan Africa, Heart 
Failure, Togo

\section{Introduction}

Ventricular non-compaction (VNC) is a rare cardiomyopathy characterized by prominent trabeculae and deep intertrabecular recesses that communicate with the ventricular cavity, along with two distinct layers of the ventricular myocardium: compacted and non-compacted [1] [2] [3] [4]. The thickness wall of ventricular consists of a thin compacted epicardial layer and a thick non-compacted endocardial layer which is likely to result from an arrest of normal ventricular myocardium embryogenesis [2] [3]. It is classified as a primary genetic cardiomyopathy or unclassified cardiomyopathy [5] [6]. Left ventricular localization is the most frequent. Bi-ventricular involvement is a very rare entity [7] [8] [9]. The estimated prevalence of VNC is $0.01 \%-0.26 \%$ in adults referred to echocardiography [4] [10] [11]. Few cases have been reported in sub-Saharan Africa [1]-[16]. Our study aims to describe the characteristics of the first cases of VNC diagnosed in Togo, one of the West-African Countries.

\section{Methods}

This was a multicenter, prospective and descriptive study, carried out over 3 years from January 2017 to December 2019 in the two university hospital in the city of Lomé which is the two reference centers for cardiology in Togo.

We included patients admitted to the two University center of Lomé for ventricular non-compaction diagnosed by echocardiography. The diagnosis of non-compaction was retained on the criteria of Jenni [17] which are:

- Presence of multiple left ventricular trabeculae $(>3)$;

- Presence of deep intertrabecular recesses;

- Visualization of colour Doppler flow within the recess and in communication with the left ventricular cavity;

- Presence of a double layered endocardial structure with an uncompacted zone/compacted zone ratio $>2$ in end systole.

Dimensions of the cardiac chambers and thickness of the interventricular septum and posterior left ventricular wall were collated. Left ventricular systolic function was calculated using the Simpson biplane method. Systolic function of the right ventricle was assessed by measurement of the tricuspid annular plane systolic excursion (TAPSE). Left ventricular filling pressures were evaluated. Pulmonary artery pressure was assessed at Doppler on the tricuspid insufficiency flow.

Complete clinical examination as well as measurement of biological parameters was undertaken; ECG and chest $\mathrm{x}$-ray were also performed. A family screening was systematically conducted for all first-degree relatives who freely accepted the screening. We were unable to perform the other explorations, in 
particular cardiac MRI and coronary angiography as well as genetic tests (because not available during the period in our country).

\section{Results}

A total of ten patients were included (six men and four women). Among the ten patients, seven were hospitalized for heart failure, one patient consulted for hypertension (case) and two cases were diagnosed during family screening ( $\mathrm{Pa}$ tients 2 and 8). The ages of the patients ranged from 16 years to 51 years with an average of 32.3 years. Table 1 summarizes the characteristics of the patients.

The clinical picture was heart failure (seven cases), including four cases of left heart failure. Three patients were asymptomatic and with a normal cardiovascular clinical examination.

Electrocardiogram showed various abnormalities: left ventricular hypertrophy (9 cases), left atrial hypertrophy (7 cases) right atrium hypertrophy (2 cases). Heart rhythm disorders were sinus tachycardia (9 cases) atrial tachycardia and ventricular extrasystole ( 1 case).

Table 1. General characteristics of patients.

\begin{tabular}{|c|c|c|c|c|c|}
\hline & Clinique & ECG & Chest X-ray & Treatment & Follow-up \\
\hline $\begin{array}{l}\text { Patient } 1 \\
38 \text { years old }\end{array}$ & $\begin{array}{l}\text { Congestive heart fail- } \\
\text { ure }\end{array}$ & LVH, LAH & Cardiomegaly & $\begin{array}{l}\text { Diuretic, ACE inhibitor, } \\
\text { beta blokers }\end{array}$ & $\begin{array}{l}\text { Compensated } \\
\text { after } 3 \text { years }\end{array}$ \\
\hline $\begin{array}{l}\text { Patient } 2 \\
34 \text { years old } \\
\text { (brother of patient } 1 \text { ) }\end{array}$ & Normal & LVH & Cardiomegaly & ACE inhibitor, beta blokers & $\begin{array}{l}\text { Asymptomatique } \\
\text { after } 3 \text { years }\end{array}$ \\
\hline $\begin{array}{l}\text { Patient } 3 \\
23 \text { years old }\end{array}$ & $\begin{array}{l}\text { Congestive heart fail- } \\
\text { ure }\end{array}$ & LVH, LAH & Cardiomegaly & $\begin{array}{l}\text { Diuretic, ACE inhibitor, } \\
\text { beta blokers, VKA }\end{array}$ & Dead after 6 months \\
\hline $\begin{array}{l}\text { Patient } 4 \\
16 \text { years old }\end{array}$ & $\begin{array}{l}\text { Congestive heart fail- } \\
\text { ure }\end{array}$ & LVH, AT & Cardiomegaly & $\begin{array}{l}\text { Diuretic, ACE inhibitor, } \\
\text { beta blokers, VKA, digoxin }\end{array}$ & $\begin{array}{l}\text { Compensated } \\
\text { after } 2 \text { years } 8 \text { months }\end{array}$ \\
\hline $\begin{array}{l}\text { Patient } 5 \\
33 \text { years old }\end{array}$ & $\begin{array}{l}\text { Congestive heart fail- } \\
\text { ure }\end{array}$ & LVH, LAH & Cardiomegaly & $\begin{array}{l}\text { Diuretic, ACE inhibitor, } \\
\text { beta blokers, VKA }\end{array}$ & $\begin{array}{l}\text { Compensated } \\
\text { after } 2 \text { year } 5 \text { months }\end{array}$ \\
\hline $\begin{array}{l}\text { Patient } 6 \\
18 \text { years old }\end{array}$ & $\begin{array}{l}\text { Congestive heart fail- } \\
\text { ure }\end{array}$ & IRBBB & Normal & Diuretic, beta blokers, VKA & Dead after 2 months \\
\hline $\begin{array}{l}\text { Patient } 7 \\
37 \text { years old }\end{array}$ & $\begin{array}{l}\text { Congestive heart fail- } \\
\text { ure }\end{array}$ & LVH, LAH & Cardiomegaly & $\begin{array}{l}\text { Diuretic, ACE inhibitor, } \\
\text { beta blokers, VKA }\end{array}$ & $\begin{array}{l}\text { Compensated } \\
\text { after } 2 \text { years } 3 \text { months }\end{array}$ \\
\hline $\begin{array}{l}\text { Patient } 8 \\
33 \text { years old } \\
\text { (brother of patient } 7 \text { ) }\end{array}$ & Normal & LVH, LAH & Normal & ACE inhibitor, beta blokers & $\begin{array}{l}\text { Asymptomatique } \\
\text { after } 2 \text { years } 3 \text { months }\end{array}$ \\
\hline $\begin{array}{l}\text { Patient } 9 \\
51 \text { years old }\end{array}$ & Normal & LVH, LAH, RAH & Normal & ACE inhibitor, beta blokers & $\begin{array}{l}\text { Asymptomatique } \\
\text { after } 1 \text { year } 3 \text { months }\end{array}$ \\
\hline $\begin{array}{l}\text { Patient } 10 \\
40 \text { years old }\end{array}$ & $\begin{array}{l}\text { Congestive heart fail- } \\
\text { ure }\end{array}$ & LVH, LAH, RAH, VES & Cardiomegaly & $\begin{array}{l}\text { Diuretic, ACE inhibitor, } \\
\text { beta blokers, VKA }\end{array}$ & $\begin{array}{l}\text { Compensated } \\
\text { after } 1 \text { year }\end{array}$ \\
\hline
\end{tabular}

LVH: left ventricle hypertrophy, LAH: left atrial hypertrophy, RAH: right atrial hypertrophy, VES: ventricular extrasystole, AT; atrial tachycardia, ACE: angiotensin converting enzyme VKA: vitamin $\mathrm{K}$ antagonist, IRBBB: incomplete right bundle branch block. 
On transthoracic echocardiography (TTE) (Table 2), isolated left ventricle non-compaction was predominant in 06 cases (Figure 1 and Figure 2). Three patients had bi-ventricular non-compaction (Figure 3) while one patient had isolated right ventricle non-compaction. The most frequent localization of non-compaction was apical segment (9 cases), apico-lateral segment (8 cases) and apicoseptal segment (7 cases). The TTE also revealed the following abnormalities: left ventricle dilatation (6 cases), left ventricle systolic dysfunction (7 cases), right ventricle systolic dysfunction (4 cases) restrictive mitral flow (8 cases), intraventricular thrombus (4 cases).

All symptomatic patients had received treatment for heart failure with systolic left ventricular dysfunction. Asymptomatic patients were put on angiotensin converting enzyme inhibitors and beta blockers. The patients with a thrombus had been put on vitamin $\mathrm{K}$ antagonist.

The follow up was marked by two deaths occurring at two months and six months after diagnosis. The first, in the clinical context of right refractory heart failure and the second was the sudden death possibly from ventricular rhythm disorder. Postmortem was not performed. The other patients are more or less clinically stable until now.

Table 2. Echocardiography data of patients.

\begin{tabular}{|c|c|c|c|c|c|c|c|}
\hline & LVEDD mm & LVEF \% & Mitral profile & Localisation & $\mathrm{NC} / \mathrm{C}$ ratio & SPAP mmHg & TAPSE $\mathrm{mm}$ \\
\hline $\begin{array}{l}\text { Patient } 1 \\
38 \text { years old }\end{array}$ & 66 & 31 & Restrictive & $\begin{array}{l}\text { Apical, septoapical, } \\
\text { apicolateral and RV }\end{array}$ & 3.66 & 45 & 24 \\
\hline $\begin{array}{l}\text { Patient } 2 \\
34 \text { years old }\end{array}$ & 60 & 63 & Restrictive & Apical & 3.11 & 5 & 27 \\
\hline $\begin{array}{c}\text { Patient } 3 \\
23 \text { years old }\end{array}$ & 57 & 26 & Restrictive & $\begin{array}{l}\text { Apical, septoapical, } \\
\text { apicolateral and } \mathrm{RV}\end{array}$ & 3.70 & 61 & 17 \\
\hline $\begin{array}{l}\text { Patient } 4 \\
16 \text { years old }\end{array}$ & 66 & 36 & Restrictive & $\begin{array}{l}\text { Apical, septoapical, } \\
\text { apicolateral, médiolateral }\end{array}$ & 2.8 & 51 & 13 \\
\hline $\begin{array}{l}\text { Patient } 5 \\
33 \text { years old }\end{array}$ & 57 & 28 & Restrictive & $\begin{array}{l}\text { Apical, septoapical } \\
\text { apicolateral }\end{array}$ & 2.7 & 67 & 15 \\
\hline $\begin{array}{l}\text { Patient } 6 \\
18 \text { years old }\end{array}$ & 45 & 65 & Restrictive & RV & 2.8 & 72 & 12 \\
\hline $\begin{array}{c}\text { Patient } 7 \\
37 \text { years old }\end{array}$ & 48 & 32 & Restrictive & $\begin{array}{c}\text { Apical, apicolateral, } \\
\text { inferoseptal, inferolateral and RV }\end{array}$ & 3.0 & 45 & 21 \\
\hline $\begin{array}{l}\text { Patient } 8 \\
33 \text { years old }\end{array}$ & 43 & 54 & Normal & $\begin{array}{l}\text { Apical, apicolateral, septoapical, } \\
\text { inféroseptal, inférolateral and RV }\end{array}$ & 5.5 & 5 & 16 \\
\hline $\begin{array}{c}\text { Patient } 9 \\
51 \text { years old }\end{array}$ & 51 & 72 & Normal & $\begin{array}{c}\text { Apical, apicolateral, } \\
\text { septoapical, mediolateral }\end{array}$ & 3.2 & 5 & 27 \\
\hline $\begin{array}{l}\text { Patient } 10 \\
40 \text { years old }\end{array}$ & 72 & 32 & Restrictive & $\begin{array}{l}\text { Apical, apicolateral } \\
\text { septoapical }\end{array}$ & 2.71 & 82 & 17 \\
\hline
\end{tabular}

LVEDD: left ventricular end-diastolic diameter, LVEF: left ventricular ejection fraction, NC: non-compaction, C: compaction, SPAP: systolic pulmonary arterial pressure, TAPSE: tricuspid annular plan systolic excursion, RV: right ventricle. 


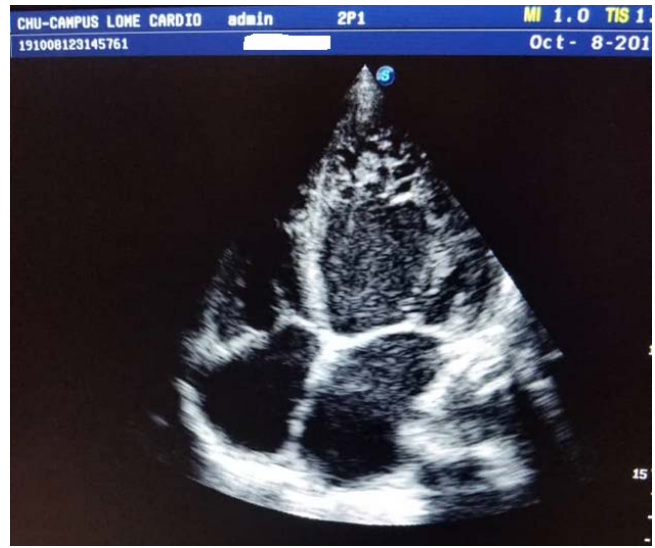

Figure 1. Apical four-chamber view of a left ventricular non-compaction with multiple trabeculations on apical septo-apical, latero-apical and mid lateral wall.

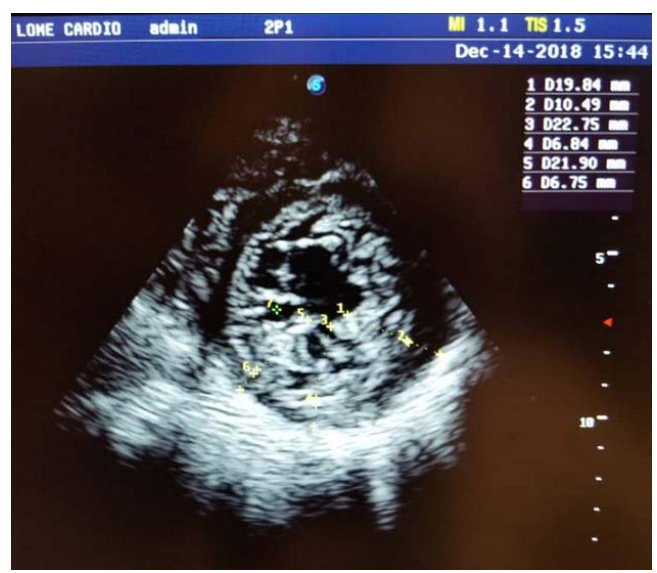

Figure 2. Parasternal small transventricular axis showing the measurement of uncompacted and compacted zone.

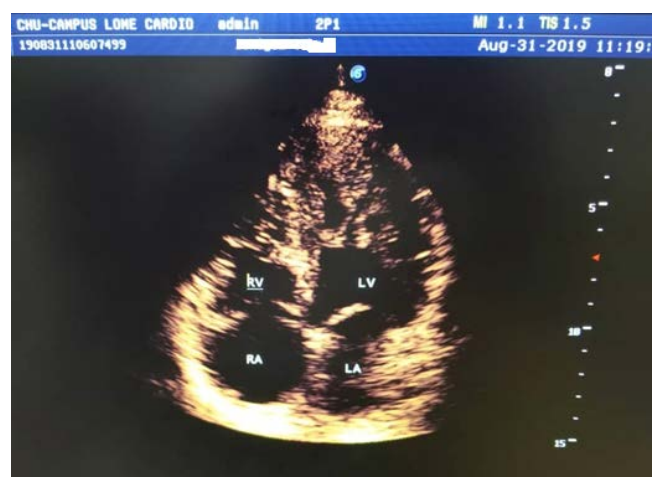

Figure 3. Apical four-chamber view of a biventricular non-compaction.

\section{Discussion}

Our study is the first in Togo, and among the few carried out in Sub-Saharan Africa; which makes it possible to complete the epidemiological data of this pathology in the region. 
LVNC, initially described in young patients, was then individualized in all age categories with a predominance of men [13]. Its prevalence is underestimated and the circumstances of its discovery are multiple [13]. The clinical manifestations of this disease are quite diverse [1] [13]. Patients may be asymptomatic. In two thirds of cases, clinical manifestations are heart failure, associated with left ventricular dilation and systolic dysfunction [13]. Atrial fibrillation (AF) occurs in $25 \%$ of cases [1] [13], and ventricular tachycardia in almost $50 \%$ [1] [13]. Sudden death accounts for $50 \%$ of deaths from this condition [1] [13]. Thromboembolic events are very frequent. In addition to the presence of trabeculation, the risk of thromboembolism is favored by impaired systolic function and AF [18] [19]. This is the case of one of our patient who had as a circumstance of discovery, an ischemic stroke.

The diagnosis is more often made on the data of the echocardiography. Based on Jenni's work, criteria have been retained [20]. These ultrasound signs make it possible to establish the differential diagnosis with normal trabeculation, with hypertrophic cardiomyopathies or dilated cardiomyopathies or with the presence of apico-ventricular thrombi. Given its recent description and diagnostic criteria long unclear, the incidence of LVNC has certainly been underestimated, and genuine LVNC has been classified as dilated cardiomyopathy [21]. Nevertheless, in tropical areas where dilated cardiomyopathies are described in large numbers, it is likely that some patients actually present with LVNC [13]. In the literature, various locations have been reported with a predominance of the apical segment [17] [22] [23]. Bi-ventricular non-compaction is rare [7] [8] [9], but six of our patients presented with bi-ventricular non-compaction.

Cardiac MRI complements the echocardiography data to identify areas of non-compaction and trabeculation, especially in patients with poor echogenicity. As such, the ratio of the thicknesses of the compacted and uncompacted areas could be an excellent diagnostic criterion associated with the other parameters described for echocardiography [17] [24]. This significant ratio beyond a value of 2.3 is calculated from measurements made in diastole at four-cavity incidence [17] [24]. In addition, MRI shows a hyper signal within uncompacted areas during T2 sequences in favor of the presence of fibrosis [19].

It has been described a gene encoding a protein of the cytoskeleton of myocardial cells, the Cypher/ZASP gene on chromosome 10: a mutation in its level could explain the particular aspect of LVNC [25]. Another mutation in the E101K gene encoding a sarcomere protein and common to other cardiomyopathies has recently been described [26]. This then results in genetic heterogeneity. There are familial forms of X-linked recessive inheritance whose gene (G4.5 at position Xq28) is similar to that of systemic myopathies and which mainly affects males [27]. In pediatric pathology, LVNC has been described in association with MLS syndrome (microphthalmia with linear skin defects) combining facial dysmorphia, microphthalmia and microcephaly [27]. The familial forms of autosomal dominant transmission seem to be the most frequent, however, sporadic 
forms have been described which can affect both sexes [28] [29].

The treatment LVNC is not codified. This treatment is of identical to treatment that of all cardiomyopathies, and depends on the clinical presentation of the patient. It is based on the management of complications such as heart failure, rhythm disorders and anticoagulation to prevent systemic embolisms [30].

The mortality rate in this disease varies from $35 \%-47 \%$ in older series [30] to $2 \%-15 \%$ in recent publications [21] [22] [31]. In sub-Saharan Africa this rate remains around $20 \%$ and this is because patients are often diagnosed at the stage of advanced heart failure [16].

\section{Conclusion}

Ventricular non-compaction is present in sub-Saharan Africa and mainly in Togo. Its prevalence is probably underestimated. This disease is encountered at any age but preferentially affects the young male subject. It presents genetic determinism as evidenced by our observations despite the non-performance of a genetic investigation. The discovery of a case should lead to the conduct of a family investigation with echocardiography performed in the family circle, and certainly a genetic investigation in the future.

\section{Conflicts of Interest}

The authors declare no conflicts of interest regarding the publication of this paper.

\section{References}

[1] Towbin, J.A., Lorts, A. and Jefferies, J.L. (2015) Left Ventricular Non-Compaction Cardiomyopathy. Lancet, 386,813-825. https://doi.org/10.1016/S0140-6736(14)61282-4

[2] Udeoji, D.U., Philip, K.J., Morrissey, R.P., Phan, A. and Schwarz, E.R. (2013) Left Ventricular Non-Compaction Cardiomyopathy: Updated Review. Therapeutic Advances in Cardiovascular Disease, 7, 260-273. https://doi.org/10.1177/1753944713504639

[3] Stanton, C., Bruce, C., Connolly, H., Brady, P., Syed, I., Hodge, D., et al. (2009) Isolated Left Ventricular Non-Compaction Syndrome. American Journal of Cardiology, 104, 1135-1138. https://doi.org/10.1016/j.amjcard.2009.05.062

[4] Ikeda, U., Minamisawa, M. and Koyama, J. (2015) Isolated Left Ventricular NonCompaction Cardiomyopathy in Adults. Journal of Cardiology, 65, 91-97. https://doi.org/10.1016/j.jjcc.2014.10.005

[5] Maron, B.J., Towbin, J.A., Thiene, G., Antzelevitch, C., Corrado, D., Arnett, D., et al. (2006) Contemporary Definitions and Classification of the Cardiomyopathies: An American Heart Association Scientific State from the Council on Clinical Cardiology, Heart Failure and Transplantation Committee; Quality of Care and Outcomes Research and Functional Genomics and translational Biology Interdisciplinary Working Groups; and Council on Epidemiology and Prevention. Circulation, 113, 1807-1816. https://doi.org/10.1161/CIRCULATIONAHA.106.174287

[6] Elliott, Persson, B., Arbustini, E., Bilinska, Z., Cecchi, F., Charron, P., et al. (2008) Classification of the Cardiomyopaties: A Position Statement from the European So- 
ciety of Cardiology Working Group on Myocardial and Pericardial Diseases. European Heart Journal, 29, 270-276. https://doi.org/10.1093/eurheartj/ehm342

[7] Ozturk, O., Ozturk, U. and Toprak, N. (2006) Biventricular Myocardial NonCompaction. Dicle Tip Dergisi, 33, 95-97.

[8] Tomar, M. and Radhakrishnan, S. (2009) Biventricular Non-Compaction: A Rare Cause of Foetal Distress and Tricuspid Regurgitation. Images in Paediatric Cardiology, 11, 1-5.

[9] Ciurznski, M., Lichodziejewska, B., Tomaszewski, A., et al. (2009) Biventricular Non-Compaction Associated with Left Ventricular Systolic and Diastolic Dysfunction and Severe Pulmonary Hypertension in a Young Man. Circulation Journal, 73, 2163-2165. https://doi.org/10.1253/circj.CJ-08-0857

[10] Arbustini, E., Weidemann, F. and Hall, J.L. (2014) Left Ventricular Non-Compaction: A Distinct Cardiomyopathy or a Trait Shared by Different Cardiac Diseases? Journal of American College of Cardiology, 64, 1840-1850.

https://doi.org/10.1016/j.jacc.2014.08.030

[11] Meneguz-Moreno, R.A., Rodrigues da Costa Teixeira, F., Rossi Neto, J.M., Finger, M.A., Casadei, C., Castillo, M.T., et al. (2016) Isolated Left Ventricular Non-Compaction Causing Refractory Heart Failure. Revista Portuguesa de Cardiologia, 35, 185.e1-185.e4. https://doi.org/10.1016/j.repce.2015.09.014

[12] Pessinaba, S., Mbaye, A., Yabéta, G.A.D. et al. (2013) Une Forme Familiale de la Non-Compaction Ventriculaire chez une Mère et Deux de ses Fils à Saint-Louis du Sénégal. Annales de Cardiologie et d' Angéiologie, 62, 51-55. https://doi.org/10.1016/j.ancard.2011.12.004

[13] Paule, P., Braem, L., Mioulet, D., et al. (2007) La Non-Compaction du Ventricule Gauche, une Cardiomyopathie du Sujet Jeune: Premières Observations Africaines. Médecine Tropicale, 67, 587-593.

[14] Mipinda, J.B., Ibaba, J., Nkoghe, D.D. and Kombila, P.A. (2011) Forme Familiale de la non-Compaction Isolée du Ventricule Gauche; cas d'une mEre et de Son fils Observé au Gabon. Annales de Cardiologie et d'Angeiologie, 62, 56-59. https://doi.org/10.1016/j.ancard.2011.04.007

[15] Peters, F., Khandheria, B.K., dos Santos, C., Matioda, H., Maharaj, N., Libhaber, E., et al. (2012) Isolated Left Ventricular Non-Compaction in Sub-Saharan Africa: A Clinical and Echocardiographic Perspective. Circulation: Cardiovascular Imaging, 5, 187-193.https://doi.org/10.1161/CIRCIMAGING.111.966937

[16] Gaye, N.D., Ngaidé, A.A., Bah, M.B., Babaka, K., Mbaye, A. and Abdoul, K. (2017) Non-Compaction of Left Ventricular Myocardium in Sub-Saharan African Adults. Heart Asia, 9, e010884. https://doi.org/10.1136/heartasia-2017-010884

[17] Petersen, S.E., Selvanayagam, J.B., Wiesmann, F., Francis, J.M., Anderson, R.H., et al. (2005) Left Ventricular Non-Compaction: Insights from Cardiovascular Magnetic Resonance Imaging. Journal of American College of Cardiology, 46, 101-105. https://doi.org/10.1016/j.jacc.2005.03.045

[18] Weiford, B.C., Subbaraov, D. and Mulhern, K.M. (2004) Non-Compaction of the Ventricular Myocardium. Circulation, 109, 2965-2971. https://doi.org/10.1161/01.CIR.0000132478.60674.D0

[19] Ichida, F., Hamamichi, Y., Miyawaki, T., Ono, Y., Kamiya, T., Akagi, T., et al. (1999) Clinicals Caracteristics of Isolated Left Ventricular Non Compaction. Journal of American College of Cardiology, 34, 233-240. https://doi.org/10.1016/S0735-1097(99)00170-9

[20] Kohli, S.K., Pantazis, A.A., Shah, J.S., Adeyemi, B., Jackson, G., McKenna, W.J., et 
al. (2008) Diagnosis of Left-Ventricular Non-Compaction in Patients with Left Ventricular Systolic Dysfunction: Time for a Reappraisal of Diagnostic Criteria? European Heart Journal, 29, 89-95.https://doi.org/10.1093/eurheartj/ehm481

[21] Murphy, R.T., Thaman, R., Blanes, J.G., Ward, D., Sevdalis, E., Papra, E., et al. (2005) Natural History and Familial Characteristics of Isolated Left Ventricular Non-Compaction. European Heart Journal, 26, 187-192.

https://doi.org/10.1093/eurheartj/ehi025

[22] Oechslin, E. and Jenni, R. (2011) Left Ventricular Non-Compaction Revisited: A Distinct Phenotype with Genetic Heterogeneity? European Heart Journal, 32, 1446-1456. https://doi.org/10.1093/eurheartj/ehq508

[23] Habib, G., Charron, P., Eicher, J.C., Giorgi, R., Donal, E., Laperche, T., et al. (2011) Isolated Left Ventricular Non Compaction in Adults: Clinical and Echocardiographic Features in 105 Patients. Results from a French Registry. European Journal of Heart Failure, 13, 177-185.

[24] Duncan, R.F., Brown, M.A. and Worthley, S.G. (2008) Increasing Identification of Isolated Left Ventricular Non-Compaction with Cardiovascular Magnetic Resonance: A Mini Case Series Highlighting Variable Clinical Presentation. Heart, Lung \& Circulation, 17, 9-13. https://doi.org/10.1016/j.hlc.2007.05.021

[25] Vatta, M., Mohapatra, B., Jimenez, S., Sanchez, X., Faulkner, G., Perles, Z., et al. (2003) Mutations in Cypher/ZASP in Patients with Dilated Cardiomyopathy and Left Ventricular Non-Compaction. Journal of American College of Cardiology, 42, 2014-2027. https://doi.org/10.1016/j.jacc.2003.10.021

[26] Monserrat, L., Hermida-Prieto, M., Fernandez, X., Dumont, C., Cazón, L., Cuesta, M.G., et al. (2007) Mutation in the Alpha-Cardiac Actin Gene Associated with Apical Hypertrophic Cardiomyopathy, Left Ventricular Non-Compaction, and Septal Defects. European Heart Journal, 28, 1953-1961. https://doi.org/10.1093/eurheartj/ehm239

[27] Kherbaoui-Redouani, L., Eschard, C., Bednarek, N. And Morville, P. (2003) Aplasie Cutanée Congénitale, Défaut de Compaction du Ventricular Gauche et Troubles du Rythme Cardiaques Graves: Un Nouveau cas de Syndrome MLS (Microphtalmia with Linear Skin Defects). Archives de Pédiatrie, 10, 224-226. https://doi.org/10.1016/S0929-693X(03)00014-9

[28] Chin, T.K., Perloff, J.K., Williams, R.G., Jue, K. and Mohrmann, R. (1990) Isolated Non Compaction of Left Ventricular Myocardium. A Study of Eight Cases. Circulation, 82, 507-513. https://doi.org/10.1161/01.CIR.82.2.507

[29] Sasse-Klaassen, S., Probst, S., Gerull, B., Oechslin, E., Nürnberg, P., Heuser, A., Jenni, R., et al. (2004) Novel Gene Locus for Autosomal Dominant Left Ventricular Non-Compaction Maps to Chromosome 11p15. Circulation, 109, 2720-2723. https://doi.org/10.1161/01.CIR.0000131865.21260.56

[30] Ritter, M., Oechslin, E., Sütsch, G., Attenhofer, C., Schneider, J. and Jenni, R. (1997) Isolated Non-Compaction of the Myocardium in Adults. Mayo Clinic Proceedings, 72, 26-31. https://doi.org/10.4065/72.1.26

[31] Aras, D., Tufekcioglu, O., Ergun, K., Ozeke, O., Yildiz, A., Topaloglu, S., et al. (2006) Clinical Features of Isolated Ventricular Non-Compaction in Adults LongTerm Clinical Course, Echocardiographic Properties, and Predictors of Left Ventricular Failure. Journal of Cardiac Failure, 12, 726-733.

https://doi.org/10.1016/j.cardfail.2006.08.002 